\title{
Bazı Çilek Çeşitlerinde Kök Bakterisi Uygulamalarının Meyve Verimi ve Verim Özellikleri Üzerine Etkileria
}

\author{
Zarife Ağgün ${ }^{1} \quad$ Mustafa Kenan Geçer ${ }^{1 *} \quad$ Rafet Aslantaş ${ }^{2}$ \\ ${ }^{1}$ Iğdır Üniversitesi, Ziraat Fakültesi, Bahçe Bitkileri Bölümü, Iğdır \\ ${ }^{1}$ Osmangazi Üniversitesi, Ziraat Fakültesi, Bahçe Bitkileri Bölümü, Eskişehir
}

Geliş tarihi (Received): 24.04.2018 Kabul tarihi (Accepted): 05.06.2018

\section{Anahtar kelimeler: \\ Çilek, kök bakterisi, meyve özellikleri}

\begin{abstract}
Özet. Bu çalışma farklı kök bakterilerinin (Azot-1, Azot-2, Fosfor-1, Fosfor-2, Azot+Fosfor), 3 çilek çeşidinde (Albion, San Andreas ve Monterey) verim ve bazı meyve özellikleri üzerine etkilerini araştırmak amacıyla yapılmıştır. Çalışmada bakteri uygulamalarından meyve verimi üzerine en etkili sonuç $99.88 \mathrm{~g} \mathrm{bitki}^{-1}$ ile Fosfor-1 uygulamasından elde edilmiştir. Bakteri uygulaması sonucunda çeşitler arasında en yüksek verim, $93.02 \mathrm{~g} \mathrm{bitki}^{-1}$ ile San Andreas çeşidinden elde edilmiştir. Bakteri uygulamaları bakımından, en yüksek meyve sayısı 3.48 adet bitki ${ }^{-1}$ ile Azot-1 uygulamasından elde edilmiştir. Bunun yanında en fazla meyve sayısı 4.28 adet bitki ${ }^{-1}$ ile Monterey çeşidindeki Azot-1 grubundan elde edilmiştir. Bakteri uygulamalarında ortalama meyve ağırlığı bakımından, en yüksek sonucu $30.17 \mathrm{~g} \mathrm{meyve}^{-1}$ ile Fosfor-2 uygulaması vermiştir. Aynı şekilde en yüksek ortalama meyve ağırlığı $32.38 \mathrm{~g} \mathrm{meyve}^{-1}$ ile San Andreas çeşidinde Fosfor-2 uygulamasında belirlenmiştir. Suda çözünür kuru madde içeriği açısından bakteri uygulamalarından en yüksek değer \%10.02 ile Azot-1 uygulamasında belirlenmiştir. Fosfor-2 uygulamasında en yüksek suda çözünür kuru madde miktarı \%10.98 ile Monterey çeşidinde elde edilmiştir. Bakteri uygulamaları sonucu en yüksek pH değere 3.97 ile Azot-2 uygulamasından ulaşılmıştır. İncelenen çilek çeşitleri arasında en yüksek pH 9.92 ile Albion çeşidinde kontrol grubundan elde edilmiştir. Bakteri uygulamalarında en yüksek titre edilir asitlik \%0.92 ile Fosfor-2 uygulamasında belirlenmiştir. Çilek çeşitlerinde ise en fazla titre edilir asit \%1.18 ile San Andreas çeşidinde Fosfor-2 uygulamasından elde edilmiştir. Çalışma sonucunda incelenen parametreler bakımından kök bakterisi uygulamalarının verim ve kalite yönünden faydalı olacağı düşünülmektedir.

mkenangecer@hotmail.com

\section{The Effects on Fruit Yield and Fruit Properties of Plant Growth Promoting Bacteria Applications on Some Strawberry Cultivars}

Keywords:
Strawberry, plant growth
promoting bacteria, fruit
properties

\begin{abstract}
This study was conducted to investigate the effect of different plant growth promoting bacteria (Nitrogen-1, Nitrogen-2, Phosphor-1, Phosphor-2, Nitrogen+Phosphor) on yield and some fruit characteristics of three strawberry cultivars (Albion, San Andreas, and Monterey). Among bacteria applications, phosphor-1 gave the highest yield amount with an average of $99.88 \mathrm{~g}$ plant-1. The highest yield amount was recorded for San Andreas cultivar (93.02 g plant-1). In fruit number, nitrogen-1 application produced the highest value (3.48 number plant-1). Besides, the highest fruit number was obtained by applying Nitrogen- 1 to Monterey cultivar with 4.28 number plant-1. Phosphor-2 among bacteria applications provided the best result in fruit index ( $30.17 \mathrm{~g} /$ fruit). Similary, the highest value of the fruit index was also obtained from San Andreas cultivar with the same application. The best soluble solid content (10.02\%) was achieved with Nitrogen-1 application. Among the strawberry cultivars, Monterey cultivar gave the highest level of soluble solid content (10.98\%). The highest $\mathrm{pH}$ value of 3.97 was obtained for Nitrogen-2 application. The highest $\mathrm{pH}$ value of 9.92 was possible with the control group in Albion cultivar. In titrable acidity, the highest value of $0.92 \%$ was obtained by Phosphor- 2 application. The highest titrable acidity value (1.18\%) was achieved by applying Phosphor-2 to San Andreas cultivar. As a result of the study, root bacterium applications are thought to be beneficial in terms of yield and quality.
\end{abstract}




\section{GíRiş}

Çilek (Fragaria vesca L.) çok geniş ekolojik sınırlar içerisinde yetiştirilebilen, güzel görünümü, rengi, kokusu ve lezzeti ile albenisi yüksek olan ve üretimi giderek artan bir meyve türüdür (Ağaoğlu 1986). Taze tüketiminin yanında reçel, marmelat, dondurma, pasta, yoğurt, süt ürünleri, alkollü ve alkolsüz içkilerde ham maddesi olarak kullanılan, özellikle ilkbaharda pazarda tüketici tarafından aranılan ve yüksek fiyatlarla satışa sunulan meyvesinin, C vitamini, mineral madde içeriğinin yüksek oluşu ve lezzetinin yanında yüksek albenisi ile tüketicinin ilgisini çekmektedir (Konarlı 1986; Hancock 1999; Cengiz 2007; Ağaoğlu ve Gerçekçioğlu 2013).

Çilek, sindirimin kolaylaştırılmasında büyük rolü olan selüloz içeriği bakımından da zengindir (Türemiş ve ark., 2000). İçeriğindeki ellajik asit ve yüksek antioksidan kapasitesi açısından kanseri engellediği açıklanmıştır (Kosar et al., 2004).

Çilek üretiminde bitki gelişimi, meyve verimi ve kalitesi açısından istenilen sonuçlara ulaşabilmenin yolu kaliteli fide kullanımı, uygun çeşit seçimi, dikim zamanı, toprak hazırlığı, bitkide stres oluşturan yüksek sıcaklıkların etkisinin değişik uygulamalarla azaltılması, gübreleme ve sulama gibi faktörlerin iyi ve dengeli planlanması çok önemlidir (Ağaoğlu 1986; Öztürk ve Demirsoy 2004). Bunun yanında gübreleme ve diğer kültürel işlemlerin etkinliğini artırabilecek bitki büyüme ve gelişmesini artırıcı humik ve fulvik asitler içeren bitki büyümesini teşvik edici ve toprak düzenleyicisi kök bakterilerinin de kullanılması önemli faydalar sağlayacaktır. Bazı kök bakterileri, bitkilerde gelişmeyi artırıcı veya biyokontrol ajanı olarak ya da her iki şekilde de davranarak bitkiler üzerinde yararlı etkide bulunurlar (Romerio 2000).

Günümüzde kök bölgesinde kendiliğinden oluşan ve bitki kök kısımları ile faydalı etkileşim içinde bulunan mikroorganizmaların önemi zamanla artmaktadır. Bitki gelişimini artıran kök bakterilerinin (Plant Growth Promoting Rhizobacteria -PGPR-) antagonistik etkilerinin yanında, bitki gelişimi ve veriminde artış sağlayarak önemli yere sahip oldukları bildirilmiştir (Altın ve Bora 2005).

Bitki gelişimini teşvik eden bakteriler; tohumun çimlenmesi, kök gelişimi, bitkinin sudan yararlanması, büyüme hormonlarının üretilmesi, faydalı mikroorganizmalar lehine kök bölgesinde mikrobiyal dengeyi değiştirmesi, mineral madde oranını düzenleyerek dolaylı olarak bitki gelişimini etkilemesi, bakteriyel ve fungal hastalıkları engellemesi, viral hastalıklara karşı koruma görevi üstlenmektedir (Siddiqui 2006).
Toprak bakterileri bitki gelişiminde patojen mikroorganizmaların bazı zararlı etkilerini engelleyerek dolaylı olarak veya mikroorganizma tarafından üretilen ve kök bölgesinde besinlerin alımını kolaylaştıran bir bileşiği sentezleyerek doğrudan etkili olabilmektedirler (Bayrak ve Ökmen 2014).

Bitki gelişmesini uyaran kök bakterilerinin (PGPR) mekanizmaları tam açıklanmamasına rağmen, biyotik ve abiyotik stres koşullarına karşı direnç sağlayarak, bitkinin kök aktivitesi üzerine olumlu etkide bulunmak suretiyle besin elementi alınımını artırmaktadırlar (Lucy et al., 2004).

Bitki gelişimini uyaran kök bakterileri (PGPR) kök bölgesini yaşam alanı edinen toprak bakterileri bitki gelişimini direkt ve in direkt teşvik edebilmektedirler. Bitki gelişimini uyaran kök bakterileri atmosferdeki serbest bulunan azotu tutup, fosforu çözen, enzim ve fitohormon üreterek bitkiler için yarayışlı olmalarını sağlamaktadır. Bitki gelişimini uyaran kök bakterilerinin bitkisel üretimde biyolojik gübre olma özelliği yanında biyolojik kontrol ajanı olma özelliğine sahip oldukları belirtilmiştir (İmriz ve ark., 2014).

Bu çalışmada, üç farklı çilek çeşidinde (Albion, San Andreas ve Monterey) kontrole kıyasla 5 farklı kök bakterisi uygulanmasının (Azot-1, Azot-2, Fosfor-1, Fosfor-2, Azot+Fosfor) meyve verim ve kalitesi üzerine etkileri araştırılmıştır.

\section{MATERYAL VE METOT}

Deneme lğdır merkeze bağlı Hoşhaber beldesinde kurulmuştur. Bu çalışmada Albion, San Andreas ve Monterey çilek çeşitleri kullanılmıştır. Uygulama; Kontrol grubu, azot fikse eden Bacillus amyloligvefaciens - MFD6 (Azot 1) ve Pseudomonas vesicularis - MFD13 (Azot 2), fosfor çözücü Bacillus viscosus - Hv26 (Fosfor 1) ve Bacillus megaterium Hk12 (Fosfor 2) ve Azot + Fosfor çözücü Pseudomonas putida - MFD3 bakterileri kullanılarak altı şekilde planlanmıştır. Çalışmada yer alan bakteriler ığdır Üniversitesi, Ziraat Fakültesi, Bitki Koruma Bölümü bakteri koleksiyonundan temin edilmiştir. Çalışma alanına ait toprak özellikleri Çizelge 1'de sunulmuştur.

Dekara 3-4 ton ahır gübresi ile gübreleme yapılmıştır. Hazırlanmış olan masuralara damla sulama sistemi kurulmuş ve yastıkların üzeri siyah malç ile örtülmüştür. 6 Nisan 2015 tarihinde frigo fideler kullanılarak sıra arası ve üzeri $35 X 35 \mathrm{~cm}$ olacak şekilde üçgen dikim sisteminde fide dikimi yapılmıştır. -80 ${ }^{\circ} \mathrm{C}$ 'de muhafaza edilen bakteriler, nutrient besi ortamına ekilerek $26^{\circ} \mathrm{C}^{\prime}$ de 3 gün inkübe edilmiştir. 
Gelişen kültürler 100p alınarak içinde nutrient broth bulunan ortama aktarılmış ve bir gece çalkalayıcıda inkübasyona bırakılmıştır. İnkübasyon sonrası gelişen bakteri solisyonunun $100 \mathrm{ml}$ si 1000 ml'ye tamamlanarak seyreltilmiş ve inokulum yoğunluğu 107 cfu $1 \mathrm{ml}$ olacak şekilde ayarlanmıştır. Uygulamadan önce solüsyona bakterinin tutunmasını sağlamak amacıyla sukroz ilave edilmiştir. Bitki kökleri hazırlanan bakteri solüsyonlarında 1 saat süreyle bekletildikten sonra dikimi yapılmıştır.

Çizelge 1. Deneme yerinin toprak özellikleri.

Table 1. Soil properties of work place.

\begin{tabular}{lc}
\hline Özellik & Değer \\
\hline Derinlik (cm) & $0-20 / 20-40$ \\
Tekstür & Killi-Tınlı \\
pH & $8.12 / 8.08$ \\
Tuz (\%) & $1.6 / 1.8$ \\
Kireç (\%) & $11.56 / 12.38$ \\
Organik Madde (\%) & 1.60 \\
N (\%) & 0.1 \\
P (ppm) & $3.2 / 3.9$ \\
K (ppm) & $126 / 136$ \\
Fe (ppm) & 3.94 \\
Mn (ppm) & 4.9 \\
Zn (ppm) & 0.27 \\
Cu (ppm) & 2.33 \\
\hline
\end{tabular}

\section{Verim Miktarı}

Her uygulamadaki meyveler hasat edilerek ve toplam verim miktarı $\mathrm{g}$ bitki $^{-1}$ olarak belirlenmiştir.

\section{Meyve Sayısı}

Hasat edilen meyveler sayılarak ve parselde bulunan bitki sayısına bölünerek bitki başına düşen meyve sayısı adet bitki ${ }^{-1}$ şeklinde hesaplanmıştır.

\section{Ortalama Meyve Ağırlı̆̆ı}

Verim miktarları meyve sayısına bölünerek ortalama meyve ağırlığı g meyve ${ }^{-1}$ belirlenmiştir.

\section{Suda Çözünür Kuru Madde Miktart}

Hasat sonrası şansa bağlı olarak seçilen beş meyve ezilerek suyu alınmış ve dijital refraktometre (Model HI-96801Hanna, German) yardımıyla suda çözünür kuru madde miktarları \% olarak belirlenmiştir.

\section{Titre Edilebilir Asitlik}

Titre edilebilir asitlik Kılıç ve ark. (1991)'e göre titrasyon yöntemiyle belirlenmiştir.

\section{Meyve pH'st}

Meyve suyu pH'sı, pH metrenin (Hanna-HI 98103) elektrot ucu meyve suyu içinde kalacak şekilde konulmuştur. Ekranda görünen değer sabit hale gelince kaydedilmiştir.

\section{Istatistiksel Analizler}

Üzerinde durulan özelliklere ilişkin tanıtıcı istatistikler $\left(\mathrm{X} \pm \mathrm{S}_{\mathrm{X}}\right)$ standart hata olarak ifade edilmiştir. Üç tekerrürlü ve her tekerrürde altı bitki olarak yürütülen çalışma sonucunda elde edilen veriler tesadüf bloklarında faktöriyel deneme deseni temel alınarak Varyans analizine tabi tutulmuştur. Önemli farklılıkların belirlenmesinde Duncan çoklu karşılaştırma testi kullanılmıştır. Elde edilen veriler IBM SPSS 23 paket programı ile analiz edilmiştir.

\section{BULGULAR VE TARTIŞMA}

\section{Verim Miktarı}

Bakteri uygulamalarının verim miktarı üzerine etkisi istatistiksel olarak önemli bulunmuştur (Çizelge 1). Bakteri uygulamalarında en yüksek meyve verimi 99.88 $\mathrm{g}$ bitki $^{-1}$ ile Fosfor-1 uygulamasından elde edilmiştir. Bakteri uygulaması sonucunda incelenen çeşitler arasında en yüksek verim $93.02 \mathrm{~g} \mathrm{bitki}^{-1}$ ile San Andreas çeşidinde belirlenmiştir. Bakteri uygulamaları bakımından; Azot-1 uygulaması ile en yüksek verim $115.59 \mathrm{~g} \mathrm{bitki}^{-1}$ ile Monterey çeşidinden elde edilirken, Azot-2 uygulamasında en yüksek verim $79.69 \mathrm{~g} \mathrm{bitki}^{-1}$ ile Albion çeşidinden sağlanmıştır. Fosfor-1 uygulaması sonucu en yüksek verim $110.84 \mathrm{~g} \mathrm{bitki}^{-1}$ ile Monterey çeşidinden sağlanırken, Fosfor-2 uygulamasında en yüksek verim $80.95 \mathrm{~g}$ bitki $^{-1}$ ile San Andreas çeşidinden sağlanmıştır. Bakteri kombinasyonları sonucu (Azot+Fosfor) en yüksek bitki başına verim de $79.45 \mathrm{~g}$ ile San Andreas çeşidinden sağlanmıştır.

Fern çilek çeşidinde bitki başına en yüksek meyve verimi $99.68 \mathrm{~g}$ ile $B$. pumilus $\mathrm{RC} 23+P$. agglomerans RCYE58 uygulamasından elde edilmiştir (Tuzlacı 2014). Özbay (2016) Albion çilek çeşidinde meyve veriminin $277.4 \mathrm{~g} \mathrm{bitki}^{-1}$ olduğunu belirlemiştir. Kılıç (2016) Sera ve sera + tünel uygulamaları sonucunda, Albion çeşidinden $134.87 \mathrm{~g} \mathrm{bitki}^{-1}$ verim elde etmiştir. Ateş

Çizelge 2. Bakteri uygulamalarının meyve verimi üzerine etkileri (g bitki ${ }^{-1}$ ).

Table 2. Effects of bacteria applications on fruit yield ( $\left.\mathrm{g} \mathrm{plant}^{-1}\right)$.

\begin{tabular}{lllll}
\hline & Albion & San Andreas & Monterey & Bakteri \\
\hline Kontrol & $64.11 \pm 19.47$ & $127.99 \pm 32.38$ & $73.45 \pm 18.46$ & $88.52 \pm 15.70 \mathbf{B}^{*}$ \\
Azot 1 & $67.60 \pm 25.70$ & $94.72 \pm 15.99$ & $115.59 \pm 35.80$ & $92.64 \pm 15.21 \mathbf{A B}$ \\
Azot 2 & $79.69 \pm 8.37$ & $79.25 \pm 13.37$ & $57.03 \pm 23.23$ & $71.99 \pm 8.93 \mathbf{B}$ \\
Fosfor 1 & $93.04 \pm 12.00$ & $95.77 \pm 7.21$ & $110.84 \pm 39.44$ & $99.88 \pm 12.40 \mathbf{A}$ \\
Fosfor 2 & $74.73 \pm 17.67$ & $80.95 \pm 12.32$ & $70.57 \pm 7.46$ & $75.42 \pm 6.75 \mathbf{B}$ \\
Azot & + & & & \\
Fosfor & $52.05 \pm 6.55$ & $79.45 \pm 21.10$ & $78.95 \pm 2.99$ & $70.15 \pm 7.87 \mathbf{B}$ \\
Çeşit & $71.87 \pm 6.42$ & $93.02 \pm 7.68$ & $84.41 \pm 10.06$ &
\end{tabular}

*: Aynı sütunda farklı harf taşıyan bakteri uygulama ortalamaları arasındaki fark önemlidir $(P<0.05)$. 
(2015) Ekoflora, Mog, Bio-One, Ferbanat L ve Bioplasma gübreleri ile farklı malç uygulamalarında organik çilek üretiminde Monterey çeşidinde $700 \mathrm{~g}$ bitki $^{-1}$ ve Albion çeşidinde $740 \mathrm{~g}^{\text {bitki }}{ }^{-1}$ verim elde etmiştir. Aromas çilek çeşidinde, Alcaligenes $637 \mathrm{Ca}$ bakteri uygulaması \% 47 oranında bitki başına verimi arttıırken ortalama meyve ağırlığını \%17.7 oranında yükseltmiştir (Ijpek ve ark., 2009).

Fern çilek çeşidinde, Bacillus OSU-142 bakterisi ve sıvı humik asit uygulamaları sonucunda özellikle verim ve verim unsurları üzerine negatif yönlü etkide bulunduğu belirlenmiştir (Pehluvan 2007).

\section{Meyve Sayısı}

Meyve sayısı üzerine bakteri uygulamalarının etkisi istatistiksel olarak önemsiz bulunmuştur (Çizelge 2). Bakteri uygulamalarıla en fazla meyve sayısına 3.48 adet bitki $^{-1}$ ile Azot-1 uygulamasında ulaşılmıştır. Çeşitler arasında ise bakteri uygulaması sonucu en yüksek meyve sayısı 3.10 adet bitki ${ }^{-1}$ ile San Andreas çeşidinden elde edilmiştir.

Bakteri uygulamalarında en çok meyve sayısı 4.28 adet bitki ${ }^{-1}$ ile Monterey çeşidinin Azot-1 grubundan elde edilmiş, Azot-2 uygulamasında ise en yüksek meyve sayısı 2.94 adet bitki ${ }^{-1}$ ile Albion çeşidinde belirlenmiştir. Fosfor-1 uygulaması sonucu en yüksek meyve sayısı 3.33 adet bitki ${ }^{-1}$ ile Monterey ve San Andreas çeşitlerinden elde edilirken, Fosfor-2 uygulamasında en yüksek meyve sayısı 2.50 adet bitki 1 ile San Andreas ve Albion çeşitlerinden sağlanmıştır. Bakteri kombinasyonları sonucu (Azot+Fosfor) en yüksek meyve sayısı da 2.67 adet bitki $^{-1}$ ile Monterey çeşidinden elde edilmiştir.

Çizelge 3. Bakteri uygulamalarının meyve sayısı üzerine etkileri (adet bitki-1).

Table 3. Effects of bacteria applications on fruit number (number plant ${ }^{-1}$ ).

\begin{tabular}{lllll}
\hline & Albion & San Andreas & Monterey & Bakteri \\
\hline Kontrol & $2.33 \pm 0.63$ & $4.17 \pm 0.53$ & $2.39 \pm 0.47$ & $2.96 \pm 0.41$ \\
Azot 1 & $2.83 \pm 0.76$ & $3.33 \pm 0.54$ & $4.28 \pm 1.29$ & $3.48 \pm 0.51$ \\
Azot 2 & $2.94 \pm 0.39$ & $2.61 \pm 0.31$ & $2.44 \pm 0.99$ & $2.66 \pm 0.33$ \\
Fosfor 1 & $3.28 \pm 0.64$ & $3.33 \pm 0.25$ & $3.33 \pm 0.68$ & $3.31 \pm 0.28$ \\
Fosfor 2 & $2.50 \pm 0.26$ & $2.50 \pm 0.00$ & $2.44 \pm 0.06$ & $2.48 \pm 0.08$ \\
Azot + Fosfor & $2.44 \pm 0.36$ & $2.66 \pm 0.50$ & $2.67 \pm 0.17$ & $2.59 \pm 0.19$ \\
Çeşit & $2.72 \pm 0.20$ & $3.10 \pm 0.20$ & $2.92 \pm 0.31$ & \\
\hline
\end{tabular}

\section{Ortalama Meyve Ağırlı̆ğ}

Ortalama meyve ağırlığı üzerine bakteri uygulamalarının etkisi istatistiksel olarak önemsiz bulunmuştur (Çizelge 3). Bakteri uygulamaları ile en yüksek ortalama meyve ağırlığını $30.17 \mathrm{~g}$ meyve $\mathrm{e}^{-1}$ ile Fosfor-2 uygulamasında belirlenmiştir. Çeşitler arasında ise uygulamalar bakımından en yüksek ortalama meyve ağırlığı San Andreas çeşidinde (29.79 g meyve ${ }^{-1}$ ) belirlenmiştir. Bakteri uygulamaları açısından; en yüksek meyve ağırığı Fosfor-2 uygulamasında $32.38 \mathrm{~g} \mathrm{meyve}^{-1}$ ile San Andreas, Fosfor-1 uygulamasında $31.18 \mathrm{~g}$ meyve $^{-1}$ ile Monterey çeşidinden elde edilmiştir. Azot-1 uygulamasında en yüksek ortalama meyve ağırlığı $28.74 \mathrm{~g} \mathrm{meyve}^{-1}$ ve Azot-2 uygulamasında $30.30 \mathrm{~g}$ meyve $^{-1}$ ile San Andreas çeşidinden sağlanmıştır. Bakteri kombinasyonları sonucu (Azot+Fosfor) en yüksek ortalama meyve ağırlığı $29.92 \mathrm{~g}$ meyve ${ }^{-1}$ ile Monterey çeşidinde tespit edilmiştir.

Bakteri uygulamaları sonucunda en yüksek ortalama meyve ağırlığı Fern çilek çeşidinde $6.70 \mathrm{~g}$ ile S. acidaminiphila RCYE47 uygulamasında belirlenmiştir (Tuzlacı 2014).

Çizelge 4. Ortalama meyve ağırlı̆̆ı üzerine bakteri uygulamalarının etkisi $\left(g\right.$ meyve $\left.{ }^{-1}\right)$.

Table 4. Effects of bacteria applications on fruit yield ( $\mathrm{g}$ plant $\left.{ }^{-1}\right)$.

\begin{tabular}{lllll}
\hline & Albion & \multicolumn{4}{l}{ San Andreas Monterey } & Bakteri \\
\hline Kontrol & $27.98 \pm 4.25$ & $29.14 \pm 3.03$ & $29.89 \pm 3.52$ & $29.22 \pm 1.99$ \\
Azot 1 & $21.75 \pm 3.99$ & $28.74 \pm 2.09$ & $26.90 \pm 0.21$ & $25.80 \pm 1.67$ \\
Azot 2 & $27.39 \pm 1.29$ & $30.30 \pm 2.84$ & $22.43 \pm 5.62$ & $26.71 \pm 2.19$ \\
Fosfor 1 & $29.43 \pm 2.72$ & $28.82 \pm 6.93$ & $31.18 \pm 5.25$ & $29.81 \pm 2.80$ \\
Fosfor 2 & $29.25 \pm 4.01$ & $32.38 \pm 4.93$ & $28.87 \pm 2.87$ & $30.17 \pm 2.09$ \\
Azot + Fosfor & $21.63 \pm 2.31$ & $28.71 \pm 3.22$ & $29.92 \pm 2.65$ & $26.75 \pm 1.89$ \\
Çeşit & $26.24 \pm 1.38$ & $29.79 \pm 1.18$ & $28.20 \pm 1.48$ & \\
\hline
\end{tabular}

\section{Suda Çözünür Kuru Madde Miktarı}

Çeşitler bakımından bakteri uygulamalarının suda çözünür kuru madde miktarı üzerine etkisi istatistiksel olarak önemli bulunmuştur (Çizelge 4). Bakteri uygulamalarında en yüksek suda çözünür kuru madde miktarı \%10.02 ile Azot-1 uygulamasında ölçülmüştür. Çeşitler arasında ise en yüksek suda çözünür kuru madde miktarı \%10.22 ile Monterey çeşidinde belirlenmiştir.

Bakteri uygulamaları bakımından; en yüksek suda çözünür kuru madde miktarı Fosfor-2 uygulamasında \%10.98 ile Monterey, Fosfor-1 uygulamasında \%9.89 ile yine Monterey çeşidinde elde edilmiştir. Azot-1 uygulaması ile en yüksek suda çözünür kuru madde miktarı \%10.54 ile Albion, Azot-2 uygulamasında ise \%10.21 ile Monterey çeşidinden belirlenmiştir. Bakteri kombinasyonları sonucu (Azot+Fosfor) en yüksek suda çözünür kuru madde miktarı \%10.22 ile Monterey çeşidinden elde edilmiştir.

Kandemir (2016) bazı çilek çeşitlerinin Karadeniz Bölgesi'nde (Samsun), örtüaltında performanslarının belirlenmesi amacıyla yapmış olduğu araştırmada suda çözünür kuru madde içeriğini en yüksek Monterey and Albion (\% 6.8-6.5) çeşitlerinden elde etmiştir. 
Fern çilek çeşidinde en yüksek suda çözünebilir kuru madde miktarı $P$. polymyxa RCYE283 uygulamasından (\%23.07) elde edilmiştir (Tuzlacı 2014).

Çizelge 5. Suda çözünür kuru madde üzerine bakteri uygulamalarının etkisi (\%).

Table 5. Effects of bacteria applications on soluble solid content (\%).

\begin{tabular}{lllll}
\hline & Albion & \multicolumn{2}{l}{ San Andreas Monterey } & Bakteri \\
\hline Kontrol & $10.34 \pm 0.69$ & $8.60 \pm 0.56$ & $10.16 \pm 0.23$ & $9.70 \pm 0.38$ \\
Azot 1 & $10.54 \pm 0.92$ & $9.03 \pm 0.27$ & $10.43 \pm 0.70$ & $10.02 \pm 0.42$ \\
Azot 2 & $10.00 \pm 0.23$ & $9.63 \pm 0.85$ & $10.21 \pm 1.03$ & $9.95 \pm 0.40$ \\
Fosfor 1 & $9.46 \pm 0.20$ & $8.35 \pm 0.35$ & $9.89 \pm 0.69$ & $9.23 \pm 0.33$ \\
Fosfor 2 & $9.08 \pm 0.38$ & $9.76 \pm 0.27$ & $10.98 \pm 1.71$ & $9.94 \pm 0.37$ \\
Azot + Fosfor & $9.80 \pm 0.55$ & $10.01 \pm 0.24$ & $9.68 \pm 0.53$ & $9.83 \pm 0.02$ \\
Çeşit & $9.87 \pm 0.23 \mathbf{A}^{*}$ & $9.23 \pm 0.22 \mathbf{B}$ & $10.22 \pm 0.26 \mathbf{A}$ \\
*: Aynı satırda farklı harfle gösterilen çeşit ortalamaları arasındaki fark \\
önemlidir (P<0.05).
\end{tabular}

\section{Meyve $\mathrm{pH}$ 'st}

Çeşitler bakımından bakteri uygulamalarının pH üzerine etkisi istatistiksel olarak önemli bulunmuştur (Çizelge 5). pH yönünden, bakteri uygulamalarından en yüksek sonucu 3.97 ile Azot-2 uygulaması vermiştir. Çeşitler arasında ise bakteri uygulaması sonucu en yüksek pH değeri Monterey çeşidinden (3.99) alınmıştır.

Ayrıca en yüksek pH değeri 9.92 ile Albion çeşidinde ve kontrol grubundan elde edilmiştir. Uygulamaları bakımından; en yüksek pH 3.94 ile Azot1 uygulamasında Monterey çeşidinde, Azot-2 uygulamasında $\mathrm{pH} 4.07$ ile Monterey çeşidinde sağlanmıştır. $\mathrm{pH}$ değerleri Fosfor-1 uygulamasında 3.92 ile Monterey çeşidinde, Fosfor-2 uygulamasında 3.99 ile Monterey çeşidinde ve Azot+Fosfor kombinasyonları sonucu 3.98 ile Monterey çeşidinde gerçekleşmiştir.

Çizelge 6. $\mathrm{pH}$ üzerine bakteri uygulamalarının etkisi. Table 6. Effects of bacteria applications on $\mathrm{pH}$.

\begin{tabular}{|c|c|c|c|c|}
\hline & Albion & San Andreas & Monterey & Bakteri \\
\hline Kontrol & $9.92 \pm 0.08$ & $3.84 \pm 0.04$ & $4.02 \pm 0.04$ & $3.92 \pm 0.04$ \\
\hline Azot 1 & $3.89 \pm 0.05$ & $3.91 \pm 0.05$ & $3.94 \pm 0.07$ & $3.92 \pm 0.03$ \\
\hline Azot 2 & $3.94 \pm 0.07$ & $3.90 \pm 0.05$ & $4.07 \pm 0.08$ & $3.97 \pm 0.04$ \\
\hline Fosfor 1 & $3.79 \pm 0.01$ & $3.82 \pm 0.05$ & $3.92 \pm 0.04$ & $3.84 \pm 0.03$ \\
\hline Fosfor 2 & $3.86 \pm 0.01$ & $3.86 \pm 0.02$ & $3.99 \pm 0.06$ & $3.90 \pm 0.03$ \\
\hline Azot + Fosfor & $3.91 \pm 0.02$ & $3.85 \pm 0.03$ & $3.98 \pm 0.03$ & $3.91 \pm 0.02$ \\
\hline Çeşit & $3.88 \pm 0.02 \mathbf{B}^{*}$ & $3.87 \pm 0.02 \mathbf{B}$ & $3.99 \pm 0.02 \mathbf{A}$ & \\
\hline
\end{tabular}

\section{Titre Edilebilir Asitlik}

Titre edilir asit üzerine bakteri uygulamalarının etkisi istatistiksel olarak önemsiz bulunmuştur (Çizelge 6). Bakteri uygulamalarıyla en yüksek asitlik değerini \%0.92 ile Fosfor-2 uygulaması vermiştir. Çeşitler arasında ise en yüksek asitlik \%0.83 ile Monterey çeşidinde belirlenmiştir.
Bakteri uygulamaları değerlendirildiğinde en yüksek asitlik değerleri ise Azot-1 uygulamasında \%0.87 ile Monterey, Azot-2 uygulamasında \%0.95 ile San Andreas, Fosfor-1 uygulamasında \%0.91 ile Monterey, Fosfor-2 uygulamasında \%1.18 ile San Andreas ve Azot+Fosfor kombinasyonunda \%0.83 ile Albion çeşidinden elde edilmiştir.

Çizelge 7. Titre edilir asitlik üzerine bakteri uygulamalarının etkisi (\%).

Table 7. Effects of bacteria applications on titrable acidity (\%).

\begin{tabular}{lllll}
\hline & Albion & San Andreas & Monterey & Bakteri \\
\hline Kontrol & $0.83 \pm 0.04^{\mathrm{ax}}{ }_{\mathrm{Ay}}$ & $0.83 \pm 0.03^{\mathrm{a}}{ }_{\mathrm{AB}}$ & $0.80 \pm 0.02^{\mathrm{a}}{ }_{\mathrm{A}}$ & $0.82 \pm 0.02$
\end{tabular}

$\begin{array}{lllll}\text { Azot } 1 & 0.69 \pm 0.11^{\mathrm{a}} \mathrm{A} & 0.69 \pm 0.02^{\mathrm{a}} \mathrm{AB} & 0.87 \pm 0.04^{\mathrm{a}}{ }_{\mathrm{A}} & 0.76 \pm 0.04\end{array}$

$\begin{array}{lllll}\text { Azot } 2 & 0.83 \pm 0.05^{\mathrm{a}} \mathrm{A} & 0.95 \pm 0.07^{\mathrm{a}}{ }_{\mathrm{AB}} & 0.78 \pm 0.08^{\mathrm{a}}{ }_{\mathrm{A}} & 0.85 \pm 0.04\end{array}$

$\begin{array}{lllll}\text { Fosfor } 1 & 0.79 \pm 0.04^{\mathrm{a}} \mathrm{A} & 0.69 \pm 0.05^{\mathrm{a}_{\mathrm{B}}} & 0.91 \pm 0.12^{\mathrm{a}} \mathrm{A} & 0.80 \pm 0.05\end{array}$

$\begin{array}{lllll}\text { Fosfor } 2 & 0.75 \pm 0.06^{\mathrm{a}} \mathrm{A} & 1.18 \pm 0.07^{\mathrm{a}} \mathrm{A} & 0.84 \pm 0.10^{\mathrm{a}}{ }_{\mathrm{A}} & 0.92 \pm 0.08\end{array}$

$\begin{array}{lllll}\text { Azot + Fosfor } & 0.83 \pm 0.06^{\mathrm{a}}{ }_{\mathrm{A}} & 0.72 \pm 0.05^{\mathrm{a}}{ }_{\mathrm{AB}} & 0.74 \pm 0.07^{\mathrm{a}} \mathrm{A}_{\mathrm{A}} & 0.76 \pm 0.04\end{array}$ $\begin{array}{llll}\text { Çeşit } & 0.79 \pm 0.02 & 0.83 \pm 0.05 & 0.83 \pm 0.03\end{array}$

x: Aynı satırda farklı küçük harf taşıyan çeşit ortalamaları arasındaki fark önemlidir $(P<0.05)$.

y: Aynı sütunda farklı büyük harf taşıyan uygulama ortalamaları arasındaki fark önemlidir $(P<0.05)$

\section{SONUÇ}

Iğdır ili sahip olduğu mikroklima özellikleri sayesinde diğer birçok meyve türünde olduğu gibi çilek üretiminde de önemli bir zenginliğe sahiptir. Bu avantajı ile çilek fidesi üretimi, fide gelişimi ve meyve verimi bakımından herhangi bir olumsuzluk yaşanmamaktadır. İlkbahar döneminde erkencilik sayesinde diğer illerde çileğin olmadığı aralıkta ve güz döneminde pazarda çileğin sonlandığı zaman diliminde ürün elde etme imkânı bulunmaktadır. Bu çalışma ile de sahip olunan avantajlara ilave olarak kök bakterisi uygulamalarının çilekte meyve verimi ve kalitesi üzerinde faydalı etkilerin olacağı anlaşılmıştır. Bu iklime uygun çeşit seçimi, dikim zamanı ve yöntemi, gübreleme ve diğer kültürel işlemlerin düzenli olarak sürdürülmesinin yanında büyüme ve gelişme bakımından önemli olan kök bakterilerinin kullanılmasının da bitki gelişimi, meyve verimi ve meyve kalitesini artırmadaki etkisinin göz ardı edilmemesi gerekmektedir.

\section{KAYNAKLAR}

Ağaoğlu YS., 1986. Üzümsü Meyveler, Ankara Üniversitesi Ziraat Fakültesi Yayınları, No: 984, Ankara.

Ağaoğlu YS ve Gerçekçioğlu R., 2013. Üzümsü Meyveler. Tomurcuk Bağ Ltd. Şti. Eğitim Yayınları No:1, Ankara.

Altın $N$ ve Bora T., 2005. Bitki gelişimini uyaran kök bakterilerinin genel özellikleri ve etkileri, Anadolu Ege Tarımsal Araştırma Enstitüsü Dergisi, 15(2): 87-103.

Ateş S., 2015. Nevşehir ili organik çilek yetiştiriciliğinde kullanılabilecek farklı gübre ve malç materyallerinin 
verim ve kalite özellikleri üzerine etkileri. Doktora Tezi, Çukurova Üniversitesi Fen Bilimleri Enstitüsü, Adana.

Bayrak D ve Ökmen G., 2014. Bitki gelişimini uyaran kök bakterileri. Anadolu Doğa Bilimleri Dergisi 5(1): 1-13.

Cengiz Ö., 2007. Erzurum şartlarında yetiştirilen çileğin verim ve kalitesinin sezon içerisindeki değişimi ve bu özelliklerin iklim verileri ile ilişkisinin belirlenmesi. Yüksek Lisans Tezi, Atatürk Üniversitesi Fen Bilimleri Enstitüsü, Erzurum.

Hancock JF., 1999. Strawberries. CABI Pub, Oxon, UK ; New York, NY, USA, 237p.

İmriz G., Özdemir F., Topal İ., Ercan B., Taş MN., Yakışır E ve Okur O., 2014. Bitkisel üretimde bitki gelişimini teşvik eden Rizobakteri (PGPR)'ler ve etki mekanizmaları. Elektronik Mikrobiyoloji Dergisi. 12(2): 1-19.

İpek M., Pırlak L., Eşitken A., Dönmez MF ve Şahin F., 2009. Kireçli Topraklarda Yetiştirilen Çilekte Bitki Büyümesini Artıran Bakterilerin (BBAB) Verim ve Gelişme Üzerine Etkileri. III. Ulusal Üzümsü Meyveler Sempozyumu, Kahramanmaraş.

Kandemir A., 2016. Bazı çilek çeşitlerinin örtü altında performanslarının belirlenmesi. Yüksek Lisans Tezi, Ondokuz Mayıs Üniversitesi Fen Bilimleri Enstitüsü, Samsun.

Kılıç O., Çopur OU ve Görtay Ş., 1991. Meyve ve Sebze İşleme Teknolojisi. Uludağ Üniversitesi Ziraat Fakültesi,Ders Notları 7: 143, Bursa.

Kılıç F., 2016. Kayseri ili Tomarza ilçesinde kısa gün ve gün nötr çilek çeşitlerinin yetiştiriciliği. Yüksek Lisans Tezi, Erciyes Üniversitesi Fen Bilimleri Enstitüsü, Kayseri.

Konarlı O., 1986. Çilek. Tarımsal Araştırmaları Destekleme ve Geliştirme Vakfı, Yayın No: 12, Yalova.
Kosar M., Kafkas E., Paydas S and Başer KHC., 2004. Phenolic composition of strawberry genotypes at different maturation stages. Journal of Agricultural and Food Chemistry, 52: 1586-1589.

Lucy M., Reed E and Glick BR., 2004. Applications of free living plant growth-promoting Rhizobacteria. Antonie Van Leeuwenhoek, 86(1): 1-25.

Öztürk A ve Demirsoy L., 2004. Değişik gölgeleme uygulamalarının Camarosa çilek çeşidinde verim ve büyüme 8 üzerine etkileri. Bahçe, 33(1-2): 39-49.

Pehluvan M., 2007. Farklı dozlarda sıvı humik asit uygulamaları ile bakteri (Bacillus OSU-142) uygulamalarının Fern çilek çeşidinde verim, verim unsurları, bitki gelişimi, meyve kalitesi ile bitki besin elementi içerikler üzerine etkileri. Doktora Tezi, Atatürk Üniversitesi Fen Bilimleri Enstitüsü, Erzurum.

Romerio RS., 2000. Preliminary Results on PGPR Research at The Universidade Federal de Viçosa, Brazil. Fifth International PGPR Workshop, 29 October - 3 November, Cordoba-Argentina.

Siddiqui ZA., 2006. PGPR: Biocontrol and Biofertilization, Chapter 4. Prospective Biocontrol Agents of Plant Pathogens. Springer Books, pp. 111-142.

Tuzlacı Hi.,, 2014. Bitki gelişimini teşvik edici bazı bakteri uygulamalarının örtü altı ve açık çilek yetiştiriciliğinde kullanılma imkânları. Yüksek Lisans Tezi, Atatürk Üniversitesi Fen Bilimleri Enstitüsü, Erzurum.

Türemiş N., Özgüven Al ve Paydaş S., 2000. Güneydoğu Anadolu Bölgesinde Çilek Yetiştiriciliği. TUBITAK, TARP yayınları, Adana. 